\title{
EVALUATION OF ECONOMIC EFFICIENCY OF KEEPING AND RAISING YOUNG CATTLE IN RUSSIA
}

\author{
Regina Gurina, Vladimir Nikitchenko, Dmitriy Nikitchenko, Anton Poddubsky, Vadim Plyushchikov \\ Peoples' Friendship University of Russia, Russia \\ gurina_rr@pfur.ru, nikitchenko-ve@rudn.ru, a.poddubskiy@mail.ru
}

\begin{abstract}
On a world-wide basis increasing of meat production, especially beef, improving of its quality and reducing of costs are of great economic importance, and therefore intensification of livestock industry through introduction of advanced technologies, organization of full feeding, creation of optimal conditions for animals' welfare, breeding of the most productive breeds of young cattle are important. Young cattle of various productivity areas in Russia are grown to different weight conditions with different technologies of keeping and battening and their live weight and carcass weight are evaluated according to the interstate standard GOST 34120-2017 according to 7 categories. In 2018 production of livestock and poultry for slaughter (live weight) in farms of all categories in Russia amounted to 9 million tons and increased by $3.7 \%$ compared to the same period in 2017. According to the Russian State Statistics of Federal Agency the volume of industrial meat production amounted to 1690.6 thousand tons for the period from January till August in 2018 (11.2\% more than at the same period in 2017). Agricultural organizations produced 626.1 thousand tons of meat for the period from January till August in 2018 (almost $8 \%$ more than at the same period in 2017). In 2018 according to the data from the Russian Ministry of Agriculture the average price of agricultural producers for cattle (live weight) was 109.57 thousand rubles per ton (w/o VAT), for half-carcass beef - 209.25 thousand rubles per ton (w/o VAT), which are also higher compared to the data for 2017. Average consumer costs for beef $-325.91 \mathrm{rubles}$ per $\mathrm{kg}$. In this work comparative assessment of average purchasing and consumer prices of live weight and carcasses of bulls and bullocks of various productivity areas was made, taking into account age of animals and technology of growing and battening by the category - super, prima, extra, excellent, good, satisfactory, low and evaluation of economic prospects for growing young stock to different weight conditions was given.
\end{abstract}

Key words: cattle, cost/price, bull-calves, bullock, category, battening/fattening.

\section{Introduction}

The meat industry of Russia plays an important role for government's economic stability, food gross production and processing industry accounts for about $15 \%$ [1]. In this connection, the efficiency of meat production and meat products is a complex economic task, in which actions of economic laws are reflected and the most important aspect of meat processing enterprise activity is manifested - its effectiveness [2;3]. In cattle breeding, one of activities to increase the production efficiency is the use of animal interbreeding. This method of breeding animals, despite its complexity, is beneficial because it allows to increase the number of livestock products, as well as to improve economic performance when using such animals. In this regard, the study of beef production economic efficiency crossbred young is relevant.

To ensure competitiveness of meat processing enterprises in the conditions of modern market, it is necessary to create conditions so that they can provide high-quality services to population and produce high-quality food, and for this it is necessary to create an effective quality management system based on regulatory documents, namely in accordance with the current standards [4]. Analysis of the USSR, Russian and a number of distant foreign countries (France, Germany, USA, Canada) standards with a high level of beef production shows that successful development of beef production is impossible without differentiated and objective selection of indicators for assessing the quality of young cattle and their carcasses. For example, in Canada the selection of young cattle according to the regulatory documentation for production of high-quality beef is determined by meat's tenderness, as the amount of connective tissue (collagen) and resistance to collagen destruction during cooking increases as animals are ageing. Classification of beef carcasses is made on the basis of the established requirements that can divide products into categories with the same characteristics and facilitate the formation of prices for beef in accordance with the quality and slaughter yield of carcass. The following factors are taken into account: animal's age, muscling, quality and release of meat on bones, fatty irrigation and marbling.

For example, in the American system, the livestock breed is essential in determining the purchase prices. Crossbred cattle are sold at the highest price - Charolais x Limousine, Hereford x Charolais, 
Angus x Brahman, etc., and animals of Simmental, Hereford, Brahmanian breeds are sold at a lower price.

As scientific studies and world practice have shown, when estimating meat productivity of cattle and, therefore, when calculating the price of beef in many countries of the world, age, breed, sex, live weight, and meat yield on bones are taken into account, and when assessing the quality of carcasses the carcass, its configuration, fullness, carcass' meat content, fat content, color of muscle and adipose tissue $[2 ; 5 ; 6]$.

In Russia, in the current standard GOST 34120-2017 the animal's sex and breed are not considered when it is assigned a category, in contrast to the standard of France, where animals' sex is paid attention to and animals are assigned to a certain category of young cattle. In the EU, carcass classification is carried out by the EUROP system in combination with the weight and category (young bulls, bullocks, heifers) that are the basis for payment to the farmer.

In special statistical journals (Meat and meat products market), Rosstat cites monthly average purchasing prices for live weight of cattle, as well as for beef (except boneless meat) and boneless beef [1]. But there are no specific data of the young stocking price value in live weight, taking into account the newly introduced seven categories according to the GOST 34120-2017. We have tried to reveal this question, using the data presented in statistical journals and our own data on the average live weight and weight of young cattle carcasses obtained earlier [5;7]. The aim of the study is to determine differences in the economic efficiency in assessing / delivering young cattle (bull-calves and bullocks) of different productivity areas depending on the age, level of raising and fattening of animals, categories according to the introduced GOST 34120-2017.

\section{Materials and methods}

Young cattle of different productivity directions are grown to different weight conditions with moderate and intensive technologies of keeping and fattening. It is planned to evaluate the live weight and mass of carcasses according to the interstate standard GOST 34120-2017 after its entry into force on January 1, 2019 in accordance with 7 categories [8]. For the convenience of describing the data, young cattle were divided into tables in age groups with a gap of 3 months, as during this period the young can gain such a live weight, which will allow it to be transferred to a higher category.

Studies of this work are based on the study and use of comprehensive analytical scientific data: zootechnical, morphological and statistical to establish the meat productivity of young cattle. Experimental studies have been carried out by setting up laboratory and research-and-production experiments, taking into account the levels of feeding of animals, sex, and age factors. The obtained data were processed by methods of variation statistics on a personal computer using Microsoft Excel and tabulated for clarity.

Based on the data obtained, a comparative assessment was made with regard to the purchasing and consumer prices of live weight and carcasses of bull-calves and bullocks of various productivity areas, taking into account the age of animals and the technology of growing and fattening by categories: super, prima, extra, excellent, good, satisfactory, low. The calculation of the purchasing and consumer prices of young cattle donated to the meat processing plant was carried out according to the following method: in the new GOST, seven categories of young cattle, average annual price of 2018 per $1 \mathrm{~kg}$ of live weight (purchasing price) 100.58 RUB transferred to the category of extra category (average fatness), and to the category of super - higher fatness, to the category of good lower average fatness.

In Russia, when calculating the price for $1 \mathrm{~kg}$ of live weight of average fatness animals, regulatory documents are used and it makes up $89.81 \%$ of higher fatness, and lower fatness of average fatness $-75.43 \%$. Taking into consideration the price for $1 \mathrm{~kg}$ of live weight of extra category animals - animals of average fatness (100.58 RUB), we have calculated the price for $1 \mathrm{~kg}$ of live weight of super categories, which amounted to $111.87 \mathrm{RUB}$, and the price for live weight of animals of lower average fatness (good) - 74.98 RUB.

The price for cattle of the prima category has been calculated by summing the prices of the super and extra categories and dividing by 2 ; the price for live mass of young animals of the excellent category is also summation of the prices for the extra and good categories and dividing by 2 . The 
young of the low category of fatness are usually accepted at meat-packing plants on a contractual price. The calculation results are summarized in Table 1.

Table 1

Estimated purchasing and consumer prices of young cattle of different categories and meat in 2018

\begin{tabular}{|c|c|c|c|c|}
\hline $\begin{array}{c}\text { Category } \\
\text { (according to } \\
\text { GOST 34120-2017) }\end{array}$ & $\begin{array}{c}\text { Price for 1 kg of } \\
\text { cattle live } \\
\text { weight of, RUB }\end{array}$ & $\begin{array}{c}\text { Price for 1 kg of } \\
\text { cattle live weight } \\
\text { of, EUR* }\end{array}$ & $\begin{array}{c}\text { Consumer } \\
\text { price for 1 kg } \\
\text { of meat, RUB }\end{array}$ & $\begin{array}{c}\text { Consumer } \\
\text { price for 1 kg } \\
\text { of meat, EUR* }\end{array}$ \\
\hline Super & 111.87 & 1.51 & 358.85 & 4.84 \\
\hline Prima & 106.22 & 1.43 & 340.56 & 4.59 \\
\hline Extra & 100.58 & 1.36 & 322.28 & 4.34 \\
\hline Excellent & 87.78 & 1.18 & 282.69 & 3.81 \\
\hline Good & 74.98 & 1.01 & 243.10 & 3.28 \\
\hline Satisfying & 62.18 & 0.84 & 203.51 & 2.74 \\
\hline Low & contractual & contractual & contractual & contractual \\
\hline
\end{tabular}

*1 EUR = 74.15 RUB (10.03.2019)

\section{Results and discussion}

The obtained calculations of the economic efficiency indicate a significant impact of the technology of rearing young cattle on the cost of production (Table 2). Own data of live weight and mass of carcasses of bull-calves and bullocks are presented from a source [7]. The purchasing price for $1 \mathrm{~kg}$ of live weight of the young grows depending on the category, level of growing and fattening, the consumer price also rises [6].

In the obtained tables with the results of the research, the criteria adopted in the zootechnical practice of Russia are used: moderate and intensive level of growing and fattening. In fact, this means that at a moderate level, up to $25 \%$ of feed from the physiological needs of animals is not delivered; with an intensive level, it means that animals receive such amount of food (balanced in nutrients and quantity), which corresponds to the physiological needs of the organism for normal growth and development.

With moderate and intensive cultivation and fattening of bull-calves at different ages, there is a discrepancy in delivery of animals in live weight and weight of carcasses. So, for example, at the age of 15 months with moderate fattening, bull-calves reached the body weight one category higher than the mass category of carcasses, and therefore the consumer price at the time of young stock delivery was higher by only 13192 RUB, which is not profitable for manufacturers. The same trend is observed at the age of 18 months. When young stock is handed over at 21 months, the categories for carcass weight and live weight coincide, which affects the profit - the consumer price is almost twice as high as the purchasing price.

It should be noted that in the process of intensive cultivation bull-calves are fatten up till 16-18 months, while receiving a higher profit, as the category of higher-quality composition and weight of handed carcasses is higher. Consumer price for carcasses amounted to $113110 \mathrm{RUB}$, which is higher by 52278 RUB than during the delivery of animals in live weight.

According to the data obtained during intensive cultivation at the age of 12 months, bull-calves reached a good category in live weight, and in the weight of carcasses the category was excellent, which is favourable for the manufacturer, when profit is obtained selling beef at the consumer price 58319 RUB, which is higher than the purchase price twice. At the age of 15 months, the same result can be noted.

In general, with the delivery of bull-calves in the highest categories - extra, prima and super, with moderate and intensive levels of growing and fattening and receiving carcasses of the corresponding categories and higher, the difference in price was $82-87 \%$.

In the process of beef production, castrated youngsters (bullocks) occupy a significant place, although it is known that castration of bull-calves lowers metabolism, decreases the growth rate of animals by $10-15 \%$ and nitrogen deposition in the body, but increases fat deposition and calorie 
content of meat. It should be noted that differences between bull-calves and bullocks increases with ageing. At 12 months, bull-calves are at $8 \%$ heavier than bullocks, at 15 months - at $14 \%$, at 20 months $-12 \%$.

Table 2

Average live weight and weight of bull-calves' carcasses of different directions of productivity at different levels of growing and fattening and their price [7]

\begin{tabular}{|c|c|c|c|c|c|c|}
\hline $\begin{array}{c}\text { Age, } \\
\text { month }\end{array}$ & $\begin{array}{c}\text { Live } \\
\text { weight, kg }\end{array}$ & Category * & $\begin{array}{c}\text { Purchasing } \\
\text { price, RUB }\end{array}$ & $\begin{array}{c}\text { Carcasses' } \\
\text { weight, kg }\end{array}$ & Category * & $\begin{array}{c}\text { Consumer } \\
\text { price, RUB }\end{array}$ \\
\hline \multicolumn{7}{|c|}{ Moderate level of growing and fattening } \\
\hline 12 & 323.9 & $\mathrm{St}$ & 20140 & 156.6 & $\mathrm{St}$ & 31870 \\
\hline 15 & 402.5 & $\mathrm{Ec}$ & 35331 & 199.6 & $\mathrm{G}$ & 48523 \\
\hline 18 & 479.2 & $\mathrm{Et}$ & 48198 & 238.3 & $\mathrm{G}$ & 57931 \\
\hline 21 & 548.0 & $\mathrm{P}$ & 58209 & 289.3 & $\mathrm{P}$ & 98524 \\
\hline 24 & 630.1 & $\mathrm{Sp}$ & 70490 & 338.9 & $\mathrm{Sp}$ & 121615 \\
\hline \multicolumn{7}{|c|}{ Intensive level of growing and fattening } \\
\hline 9 & 301.3 & $\mathrm{St}$ & 18735 & 149.8 & $\mathrm{St}$ & 30486 \\
\hline 12 & 396.1 & $\mathrm{G}$ & 29700 & 206.3 & $\mathrm{Ec}$ & 58319 \\
\hline 15 & 487.6 & $\mathrm{Et}$ & 49043 & 263.4 & $\mathrm{P}$ & 89704 \\
\hline 18 & 572.7 & $\mathrm{P}$ & 60832 & 315.2 & $\mathrm{Sp}$ & 113110 \\
\hline 21 & 659.0 & $\mathrm{Sp}$ & 73722 & 367.3 & $\mathrm{Sp}$ & 131806 \\
\hline
\end{tabular}

* satisfied - St, excellent - Ec, good - G, extra - Et, prima - P, super - Sp

When analysing the data of bullocks' purchase, it should be noted that they reach the extra category with a moderate level of growing and fattening only by 21 months and by 15 months with an intensive level of fattening, i.e. always have lower live weight in contrast to bullocks at the same age, therefore, the income from the delivery of animals and their carcasses is less. With a moderate level of growing and fattening in the age of 15 months, there is a discrepancy between the categories when assessing the young's live weight and its carcasses. In the category of "good" average live weight, bullocks were sold at a price of 25036 RUB, and in the category of "satisfactory" - consumer price was 32887 RUB, which is higher at 7851 RUB. At the age of 18-24 months, the categories of handed carcasses coincide with the categories of animals that are handed over by live weight (Table 3 ). The cost of sold carcasses at the consumer price exceeds at $79 \%$ than the payment for the young stock in live weight.

Table 3

Average live weight and weight of bullocks' carcasses of different directions of productivity at different levels of growing and fattening and their price [7]

\begin{tabular}{|c|c|c|c|c|c|c|}
\hline $\begin{array}{l}\text { Age, } \\
\text { month }\end{array}$ & $\begin{array}{c}\text { Live } \\
\text { weight, } \mathrm{kg}\end{array}$ & Category * & $\begin{array}{l}\text { Purchasing } \\
\text { price, RUB }\end{array}$ & $\begin{array}{l}\text { Carcasses' } \\
\text { weight, } k g\end{array}$ & Category* & $\begin{array}{c}\text { Consumer } \\
\text { price, RUB }\end{array}$ \\
\hline \multicolumn{7}{|c|}{ Moderate level of growing and fattening } \\
\hline 12 & 267.5 & $\mathrm{~L}$ & contractual & 126.8 & $\mathrm{~L}$ & contractual \\
\hline 15 & 333.9 & $\bar{G}$ & 25036 & 161.6 & $\mathrm{St}$ & 32887 \\
\hline 18 & 402.7 & Ec & 35349 & 210.4 & Ec & 59478 \\
\hline 21 & 478.2 & Et & 48097 & 245.8 & Et & 79216 \\
\hline 24 & 537.5 & $\mathrm{P}$ & 57093 & 279.1 & $\mathrm{P}$ & 95050 \\
\hline \multicolumn{7}{|c|}{ Intensive level of growing and fattening } \\
\hline 9 & 289.8 & $\mathrm{~L}$ & contractual & 144.3 & $\mathrm{~S}$ & 29366 \\
\hline 12 & 373.4 & $\mathrm{G}$ & 27998 & 205.1 & Ec & 57980 \\
\hline 15 & 453.1 & $\mathrm{Et}$ & 45573 & 246.2 & $\mathrm{Et}$ & 79345 \\
\hline 18 & 533.5 & $\mathrm{P}$ & 56668 & 294.1 & $\mathrm{P}$ & 100159 \\
\hline 21 & 612.1 & $\mathrm{Sp}$ & 68476 & 339.6 & $\mathrm{Sp}$ & 121774 \\
\hline
\end{tabular}

* low - L, satisfied - St, excellent - Ec, good - G, extra - Et, prima - P, super - Sp 
At the age of 12 months with an intensive level of cultivation, bullocks reached the mass of carcasses in the category higher than in live weight. Thus, with the delivery of carcasses of an excellent category with a mass of $205.1 \mathrm{~kg}$, a profit of $57980 \mathrm{RUB}$ was obtained, which is higher as the purchasing price for live weight of bullocks twice. Bullocks with intensive cultivation technology reached the category of prima early at the age of 18 months, but with a moderate level of cultivation only by 24 months, which will also affect the purchasing price in the future and, as a result, the consumer price.

Bullocks reached the categories of super at the age of 21 months with an intensive level of feeding, the profit at the time of delivery at the consumer price amounted to 121774 RUB in comparison with the moderate technology of cultivation and the animals at this age achieve the extra category and the profit of 79216 RUB.

\section{Conclusions}

In conclusion, it should be noted that this article for the first time provides the calculation of purchasing and consumer prices, which are established when evaluating live weight and carcasses of young cattle in different directions of productivity in seven categories according to the GOST 34120 2017, put into effect 01.01.2019.

1. With the same live weight in young cattle of different ages, the composition of carcasses will be different. Meat of young animals has higher protein content and is more in line with the modern consumer requirements. At the same time, with animals' ageing, the feed cost per unit of production increases, the prime cost rises.

2. Despite the fact that active work is underway in the field of national and interstate standardization, however, classification procedures of animals and carcasses obtained from them in different countries have significant differences. In this article, we have resulted in price differences in bull-calves and bullocks' delivery of different productivity directions of different age, depending on the level of growing and fattening.

3. Discrepancies were established during the delivery of young stock in live weight with the output of carcasses, which further influences the costs of meat processing plants and, as a consequence, the consumer price of meat and meat products.

The content of the article indicates that the GOST 34120-2017 "Cattle for slaughter, beef and veal in carcasses, half carcasses and quarters" should be harmonized, taking into account the positive practice of the leading countries with regard of beef production, the indicators that complement the objectivity of determining the meat quality of animals of different ages, sex, direction of productivity and the level of growing and fattening.

\section{Acknowledgements}

The publication was prepared with the support of the RUDN University Program "5-100".

\section{References}

[1] Небурчилова Н.Ф., Осянин Д.Н, Петрунина И.В. Текущая ситуация на рынке мяса и мясных продуктов в январе-июле 2018 года (Neburchilova N.F., Osyanin D.N., Petrunina I.V. Current situation in the market of meat and meat products in January-July 2018.)// Рынок мяса и мясных продуктов. - 2018, № 8., с. 2-9. (In Russian)

[2] Skarzynska A., Abramczuk L. Results of farms specializing in production of cattle for fattening in selected European Union countries. Scientific Papers. Series "Management, Economic Engineering in Agriculture and Rural Development", 2018; T.18, N 2., pp. 421-430.

[3] Liang Y., Xiao-hua P., Ben-hai X., Zhen-gang Y. A Development of a Beef Production Traceability System Covering Rearing to Marketing Sections. Acta veter.zootechn.sinica, 2015; Vol.46,N 8., pp. 1383-1389.

[4] Gurina R., Poddubsky A., Sinenko V. Integrated quality management system at food enterprises in Russia// Engineering for Rural Development, 2018, pp. 883-886.

[5] Никитченко В.Е., Никитченко А.В., Гурина Р.Р., Экономическая оценка молодняка крупного рогатого скота мясного направления продуктивности (Nikitchenko V.E., 
Nikitchenko A.V., Gurina R.R., Economic evaluation of the young cattle's meat productivity)// Все о мясе, 2014. -№ 3., с. 9-12. (In Russian)

[6] Morales L.E. The effects of international price volatility on farmer prices and marketing margins in cattle markets. International Food and Agribusiness Management Review, 2018; T.21, N 3. pp. 335-350.

[7] Никитченко, В.Е., Никитченко Д.В., Сусь И.В., Гурина Р.Р. Товарная оценка молодняка крупного рогатого скота разного направления продуктивности (Nikitchenko V.E., Nikitchenko D.V., Sus I.V., Gurina R.R. Product evaluation of the young cattle in different directions of productivity)// Bce о мясе.-2014.- № 1, с. 32-35. (In Russian)

[8] ГОСТ 34120-2017 Крупный рогатый скот для убоя. Говядина и телятина в тушах, полутушах и четвертинах. Технические условия. (GOST 34120-2017 Cattle for slaughter, beef and veal in carcasses, half carcasses and quarters. Technical conditions)-2018., 20 c. (In Russian) 